\title{
Valuing grazing use on public land
}

\author{
E. TOM BARTLETT, L. ALLEN TORELL, NEIL R. RIMBEY, LARRY W. VAN TASSELL, AND DANIEL W. \\ MCCOLLUM
}

Authors are Professor, Department of Rangeland Ecosystem Science, Colorado State University, Fort Collins, Colo. 80523; Professor, Department of Agricultural Economics and Agricultural Business, New Mexico State University, Las Cruces, N.M. 88003; Professor, Department of Agricultural Economics and Rural Sociology, University of Idaho, Caldwell, Ida. 83605; Professor and Head, Department of Agricultural Economics and Rural Sociology, University of Idaho, Moscow, Ida., 83844; and Economist, U.S. Forest Service, Rocky Mountain Research Station, Fort Collins, Colo.

\begin{abstract}
The value of public land forage has been of key interest since grazing fees were first established on federal lands. Additionally, knowing the value of rangeland forage is important for assessing the economics of range improvements, grazing systems, and alternative land uses. It is important for resource value comparisons and impact assessments when public land forage is allocated to other uses. In this synthesis paper, we review the various methods that have been used to value public land forage and discuss the advantages and limitations of each. We highlight that past valuation efforts have concentrated on the value of public land forage for livestock production and, consequently, underestimated total forage value and rancher willingness to pay for forage and grazing permits. These research efforts failed to recognize that amenity and lifestyle attributes from ranch ownership and forage leasing play important roles in the use and pricing of rangeland forage. We review the numerous studies conducted to estimate public land forage value and suggest modifications to improve future value estimates. Because lifestyle attributes of ranch ownership have so strongly influenced ranch values and what ranchers are willing to pay for grazing use on public lands, we find the market value of federal grazing permits and a modification of the standard contingent valuation method for valuing non-market goods to hold the greatest promise for valuing public land grazing.
\end{abstract}

Key Words: Forage value, grazing fees, grazing leases, hedonic models, contingent valuation, public land grazing

Knowing the value of forage is a necessary component in many economic studies. Forage value estimates are needed for assessing the economics of range improvements, grazing systems, and alternative land uses. Rural appraisers use estimates of forage value in ranch income appraisals. The economic impact of changing forage use and availability starts with an estimate of the economic value of the grazing capacity potentially eliminated or redirected. These assessments and valuations are often controversial, especially when public land grazing is considered.

Much of the prior work to value rangeland forage has dealt with the appropriate grazing fee for public land grazing; the key issue being the level of economic benefits received by grazing users of public lands (Gee 1981, Torell et al. 1993, USDA/USDI

Research was funded in part by U.S. Forest Service Research Joint Venture No. 00-JV-11221617-221.

Manuscript accepted 26 Dec. 2001.
Resumen

El valor del forraje de tierras públicas ha sido de interés clave desde que los pagos por pastoreo fueron establecidos en tierras federales. Adicionalmente, el saber el valor del forraje de los pastizales es importante para tasar la economía de las mejoras al rancho, de los sistemas de pastoreo, y de los usos alternativos del suelo. Es importante para comparaciones del valor de los recursos y evaluaciones de impacto cuando la tierra pública es destinada a otros usos. En esta síntesis revisamos los diferentes métodos que han sido utilizados para valuar el forraje de tierras públicas y se discuten las ventajas y limitaciones de cada uno. Enfatizamos que los esfuerzos de valuación utilizados en el pasado se han concentrado en el valor del forraje de tierras públicas utilizado en la producción de ganado, y consecuentemente han subestimado el valor total del forraje y la disposición del ranchero de pagar por el forraje y por los permisos de pastoreo. Los esfuerzos de esta investigación fallaron en reconocer que los atributos amenidad y estilo de vida de poseer un rancho y arrendar pastizales juegan roles importantes en el uso y precio del forraje. Revisamos los numerosos estudios que condujeron a estimar el valor del forraje en tierras públicas y sugerimos modificaciones para mejorar estimaciones del valor futuro. Dado que los atributos del estilo de vida de poseer un rancho han influenciado fuertemente el valor de los ranchos, así como lo que los rancheros están dispuestos a pagar por el uso de pastizales en tierras públicas, encontramos que el valor de mercado de los permisos federales de pastoreo y una modificación al método estándar de valuación contingente para valuar productos fuera del mercado, como una de las grandes promesas para valuar pastoreo en tierras públicas.

1986). Comparison to private rangeland lease rates has been the primary method to value public forage. Yet, average private lease rates may or may not reflect the total benefit received from the use of range forage on federal lands. Hence, the focus of this paper goes beyond the grazing fee issue and reviews numerous ways forage can be valued on public rangelands. We approach forage valuation from the basis of total value to resource users and consider resource values for livestock production and other values associated with rangelands and ranching that we call quality-of-life (QOL) factors. These amenity and lifestyle attributes from ranch ownership and forage leasing have been shown to play important roles in the use and pricing of rangeland forage. "Forage value" in our application is thus expanded beyond its value for livestock production to include other attributes such as 
exclusive access to permits, the desirable ranching and rural lifestyle, open spaces, and the solitude and tranquil experiences realized or perceived to exist when using public lands for grazing.

In this synthesis paper, we first review the theoretical basis for valuing rangeland forage, both for its value in livestock production and for the value realized from recreation, cultural experiences, open spaces, and scenic views associated with the rural ranching lifestyle. We review the numerous methods that can be used to value forage and discuss the advantages, disadvantages, and limitations of each. We evaluate whether there are regional differences in forage values and relate these differences to the question of whether public land grazing fees should be different for different areas of the West. We recognize there are many values associated with rangelands (USDA 1998). Limiting the scope of this paper to rangeland forage and its use requires a rethinking of the benefits obtained from grazing use of public rangeland.

Over the history of administered grazing on public lands, updates of forage value have varied from periodic appraisals based upon comparable private lands (Rachford 1924, Tittman and Brownell 1984) to indexing values based on private lease rates, livestock prices, and prices paid on a national basis (Dutton 1953, Brokken and McCarl 1987). Updating forage values as markets and grazing conditions change is a critical factor for grazing fee policy. Thus, we discuss different ways public land forage values might be updated through time and how appropriate fee estimates could be established using each of the alternative valuation procedures.

\section{Theoretical Basis for Valuing Public Land Forage}

\section{Valuing Forage for Livestock Production}

The theoretical justification for various forage valuation procedures has historically been based on the premise that ranchers maximize profit. Forage has a derived demand in the production of livestock, and the forces of supply and demand operate to establish prices within a competitive market (Jensen and Thomas 1967). Establishing the value of public land forage based on its value for livestock production has a long history with strong ties to the standard production economic model of a profit-maximizing firm. These production principles were first highlighted in an economic model developed as part of grazing fee research conducted in Utah (Roberts 1963). This model formed the traditional basis for valuing forage on public lands.

As shown by Roberts (1963), Nielsen and Wennergren (1970), and Brokken and McCarl (1987), the Utah forage value model implies the standard condition for profit maximization. Profit-maximizing firms use inputs to the point where the value of the marginal product of factor $i$ $\left(\mathrm{VMP}_{\mathrm{i}}\right)$ is equal to the marginal factor cost of input $\mathrm{i}\left(\mathrm{MFC}_{\mathrm{i}}\right)$. VMP $\mathrm{i}$ is the product of 1) marginal physical product $\left(\mathrm{MPP}_{\mathrm{i}}\right)$, which is the added productivity (output) of input factor $i$ when used to produce livestock and 2) the marginal revenue from selling the product, which is the price of the product under perfect competition. Under this construct, grazing resources are valued for their MPP and the value of the livestock product to be sold.

By adjusting stocking rates to the level where VMP is equal to MFC, a profitmaximizing level of forage use and output is determined. However, the profit-maximizing level of range forage use might differ from use limits imposed by land management agencies. Roberts (1963) demonstrated that, if the profit-maximizing rancher must set forage harvest where VMP exceeds MFC, an excess value accrues to the permittee. With a long-term lease, this excess value would be capitalized into a permit value, or the value of the base property of the ranch. Thus arises the traditional theory of why public land grazing permits have market value, and the widespread belief that the existence of permit value suggests public land forage is under-priced.

The standard economic model of production and optimal input use implies certain behavioral postulates and requires certain conditions for validity. Observation has shown shortcomings in using the "theory of the firm" to explain the behavior of livestock producers in leasing forage. Most notably, the value of private and public grazing land use does not appear to arise strictly from livestock production (Martin and Jeffries 1966). Ranchers have motives beyond profit that influence their willingness to pay for forage, buy ranches, and remain in business when other investments would provide a higher rate of investment return (Torell and Bailey 2000, Torell et al. 2001).

\section{Valuing Forage for Quality-of-Life Reasons}

Buying ranches or leasing forage to obtain the associated lifestyle, as well as the revenue that accrues from agricultural production, suggests a household production framework. Based on work by Becker (1965) and Lancaster (1966a, 1996b), households are said to combine goods and services with time and human capital to produce an output. In this case, ranchers are thought to realize satisfaction and utility from cultural experiences, open spaces, recreation, and scenic views associated with the ranching lifestyle. They maximize utility, of which profit is 1 component, subject to a budget constraint. Ranching as a way-of-life is a good that provides utility and satisfaction to the ranch owner and family.

There are at least 3 indicators that most ranchers are not motivated primarily by profit from livestock production. First, returns to both private and public land ranches are low by any standard measure of investment performance. Depending on ranch size, nominal rates of return from livestock production have typically been reported to range from negative amounts to about $3 \%$, averaging no more than $2 \%$ (McGrann 2000, Torell et al. 2001, Smathers et al. 1998b, Workman 1986). By comparison, an American Agricultural Economics Association report on commodity cost and return (CAR) estimation (AAEA 1998) found the nominal opportunity rate that agricultural investors could have made over the $1964-1996$ period by investing their money in non-agricultural investments with similar risk was from $5 \%$ to $9 \%$.

A second indicator that ranchers do not adhere to a strong profit motive is the relatively small part of land value explained by livestock production value. Trends in ranchland values seem to be impervious to the price of beef and net livestock returns. Adkins and Graeber (1978) found that the productive value of ranches in the Hill Country of Texas accounted for about $10 \%$ of ranchland market value, but in the High Plains, the productive value accounted for nearly $50 \%$ of market value. Similarly, Pope (1985) found population density, aesthetic differences, quality of deer hunting, and proximity to major metropolitan centers explained most differences in Texas land values. Torell and Bailey (2000) found no statistical relationship between variation in net annual livestock returns or variation in beef prices 
and recent trends in New Mexico ranch values. As noted by Barkema and Novack (2000) in an assessment of farm and ranch values in the various Federal Reserve Districts, "During 1999-2000 the value of ranches in the mountain states climbed the most, influenced more by nonfarm investors' demand for scenic mountain views than by ranchers' demand for additional grazing land" (p. 39). It is widely recognized that western ranches are overpriced relative to what the cows will buy and pay for (Torell et al. 2001, Martin and Jeffries 1966).

The third indicator that profit is not the primary motive is that western ranchers list quality of life as a primary reason for ranching. Numerous authors have reviewed the motives of farmers and ranchers (Martin 1966, Martin and Jeffries 1966, Smith and Martin 1972, Harper and Eastman 1980, Biswas et al. 1984 , Sullivan and Libbin 1987, Bartlett et al. 1989, Young and Shumway 1991, Gentner 1999, Liffman et al. 2000, Rowe et al. 2001, Torell et al. 2001, Tanaka and Gentner 2001). These studies show, for most agricultural producers, the desirable quality-of-life (QOL) attributes associated with rural living are more important goals than profit maximization.

To help define social and economic characteristics of western public land ranchers, Gentner (1999) conducted a mail survey of Bureau of Land Management (BLM) and U.S. Forest Service (USFS) grazing permittees. The goals and objectives of public land ranchers varied from a high ranking for QOL factors to a strong emphasis on profit maximization for ranchers more dependent on ranching for income. Gentner (1999) found all types of public land ranchers ranked QOL factors above profit maximization as reasons for ranching. This suggests "all ranchers are economic satisficers with varying degrees of importance placed on earning potential from the ranch" (Gentner 1999, p. 49). All ranch groups listed the complementary relationship between land ownership and family tradition, culture, and values as a primary reason for owning the ranch.

Significant policy implications arise when the primary reason for ranch ownership and livestock production is not profit. As noted by Torell et al. (2001), when ranch market values are driven by nonprofit factors, disparities will exist between the livestock production value and market value of forage. Traditional economic models used to evaluate land- use policies will be inadequate and alternative valuation procedures, such as contingent valuation, willingness-to-pay studies, and hedonic models, must be used to consider QOL factors in the forage valuation process.

\section{Methods of Valuing Grazing Use}

There are a number of methods that have been used to estimate forage value. These methods have included lease-price observation in the private forage market, comparing total costs (fee and non-fee) of grazing public and private lands, using the value of public land grazing permits to imply the value of forage, economic analysis of factors associated with public land livestock production, competitive bidding processes, and contingent valuation of public land forage. This section summarizes past work on each of these valuation procedures, detailing strengths and weaknesses of each method. Procedures that could be used to update forage values using each method are also discussed.

\section{Market Price Comparison}

Leasehold value and comparison to the private forage market is the primary way farms and ranches are valued in income appraisals. Competition for leased forage will supposedly drive lease prices to the value of the marginal product of forage in the production of livestock, and average lease rates indicate earning potential from land ownership. Observed market prices have traditionally been used to calculate expected annual earnings from a ranch property and the capitalized value of the expected future income stream (ASFMRA/AI 2000).

Comparison to the private forage market is based on the alternative cost doctrine, whereby a profit maximizing lessee of forage will not pay in excess of the amount that must be paid for the next best alternative. Thus, if private and public forage are perfect substitutes, economically motivated ranchers should be willing to pay equal amounts for the 2 sources of forage. Because of policies governing the issuance and regulation of public grazing permits, there is no competition to determine public forage value. Consequently, it has been generally accepted that the fair market value of public lands would have to be estimated indirectly by comparing to the private forage market (USDI/USDA 1977).

Nearly all valuations of public land forage have used the private forage market to imply value. These comparisons date back to 1916 when the U.S. Forest Service used the rental value of some 900 tracts of private land to determine the apparent market value of Forest Service forage (Dutton 1953). Federal grazing fee studies have continued to rely on private forage market price comparisons as one of the primary indicators of market value (Rachford 1924; USDA/USDI 1986, 1992, USDI/USDA 1977, 1993, 1994).

When tracts of land have comparable characteristics, it is widely believed that comparison to the private forage market is valid. However, adjustments must be made for any observed differences in leasehold arrangements, and it is often difficult to find comparable rental information on ranch properties. Further, the validity of the comparison depends on the assumption of perfect competition. Kearl (1989) questioned this assumption, given the observation that, in many areas of the West, there are relatively few sellers of forage. He felt the forage market was characterized by monopolistic competition with price discrimination, citing the lack of private grazing resources in geographic proximity to public lands as support for his market characterization.

Private landowners often provide rights and services to grazing tenants that are not provided on public lands. These rights and services have value to the lessee that is incorporated into the private land lease rate. Many comparisons to the private forage market have failed to adequately adjust for lessor-provided services and to recognize other lease and land-tract differences. Some of the earliest grazing fee studies did adjust for lease differences. The Rachford (1924) appraisal and lease rate comparison compared 1,675 private land tracts (6.56 million ha) to some 10,000 USFS allotments that had been rated for compatibility based on forage availability, distance to water, topography, and accessibility. When the appraisal results and comparison were presented at public meetings, there was widespread agreement as to the fairness of the comparison method. But, as a business proposition, public land ranchers were unanimous in opposing the fee increases proposed at the time (Dutton 1953). By comparison, the 1986 grazing fee report and mass appraisal of forage (USDA/USDI 
1986) was severely criticized by western university economists and others for the minimal adjustments (5\% for conditions of use and $10 \%$ for lease prepayment) that were made between private and public lands and the mass appraisal procedures used (Dudley and Rostvold 1992, Kearl 1989, USDA/USDI 1992).

Attempts have been made to statistically determine how private land lease rates vary when selected services are provided with forage leases. These studies have generally used regression procedures on a cross-section of private land leases to estimate service and forage values (Gray et al. 1983, Fowler et al. 1985, Torell et al. 1988, Torell and Bledsoe 1990, Rimbey et al. 1992, 1994). Because lessor services tend to be provided in blocks, these regression studies had problems with multicollinearity. Consequently, principal components regression was used to estimate service values in Fowler et al. (1985), and more broadly grouped categories of services were used in the other studies. These studies considered the value of landlord-provided services for daily care of livestock, watering livestock, maintenance of fences and facilities, and grazing access to the leased property. They did not value the hunting, fishing, and timber-harvest rights, exclusion of access to outside parties, and differences in stewardship requirements.

Results of 6 New Mexico lease rate studies, conducted primarily to evaluate the market value of New Mexico State Trust Lands, consistently found the value of landlord services to comprise about $30 \%$ of the average lease price (Torell and Fowler 1992). Rimbey et al. (1992) found a slightly higher percentage in Idaho, but this included an adjustment for lease prepayment that was not considered in the New Mexico studies. The Idaho study found the value of services to average $36 \%$ or $39 \%$ of the average lease price, depending on whether the National Agricultural Statistics Service (NASS) survey lease rate or a University of Idaho survey rate was used.

Using the $30 \%$ average service valuation in their calculations, LaFrance and Watts (1995) estimated the average composite real rate of return on private grazing lands was $3.37 \%$. They noted that this value was nearly identical to the $3.35 \%$ rate estimated from New Mexico ranch sales by Torell and Doll (1991), and concluded that the $30 \%$ average service valuation was appropriate across all 11 western states. The implied forage valuation procedure was to multiply average private land lease rates reported by USDA-NASS (2001), or other sources, by $70 \%$ to estimate net forage value.

Comparison of public forage use to the private forage market have historically assumed the market lease rate reflects the value of forage for livestock production. Yet, the market price comparison method does not necessarily give the value of forage for livestock production alone. Theoretically, ranchers base their willingness to pay for forage on livestock earning potential, but the actual price paid can result for a combination of reasons. Martin and Jeffries (1966, p. 239) noted private and public land forage lessors pay too much relative to livestock earnings potential and concluded, "Evidently private lands are not rented merely for the purpose of profits from beef production either." Recent cost-and-return studies confirm that the willingness to pay more for private leased forage than justified by livestock production has continued (Torell et al. 2000, Smathers et al. 1998a). Leasing private lands provides those who cannot afford to buy ranches the opportunity for livestock income and Quality of Life (QOL) experiences.

Forage values implied from comparison to private grazing markets can be estimated annually. This comparison is currently made each year to update the Public Rangelands Improvement Act (PRIA) fee formula ${ }^{1}$. Because lease rate surveys are conducted and published annually, no updating mechanism is necessary.

Perhaps the major limitation of the lease price comparison method is finding private leases that are comparable to public lands and making appropriate adjustments for lease differences that exist. Various lease rate comparison studies support adjusting published NASS private lease rates downward in each state by a factor of about $30 \%$ to account for services provided to lessors of private forage that are not provided on public lands, but this percentage is variable and broadly applied. Further, comparison to private land lease rates does not recognize the higher nonfee grazing costs shown to exist on public

\footnotetext{
${ }^{1}$ The PRIA fee formual is calculated as $\mathrm{Fee}_{t}=$ $\$ 1.23 \times\left(\mathrm{FVI}_{\mathrm{t}-1}{ }^{-}+\mathrm{BCPI}_{\mathrm{t}-1}-\mathrm{PPI}_{\mathrm{t}-1}\right) / 100$, where $\mathrm{FVI}$ is the Forage Value Index, BCPI is the Beef Cattle Price Index, and PPI is the Prices Paid Index. The PRIA formula with modification by Executive Order in 1986 is stil used to set public land grazing fees.
}

lands (USDI/USDA 1977, Bartlett et al. 1993).

\section{Total Cost Approach}

The total cost approach is another form of market price comparison that has been used to value public land forage. This valuation approach is based on the belief that "the fair market value of public range forage used for grazing is equal to the lease rate for private forage adjusted by the amount that the cost of grazing on private lands is less than the cost of grazing on public lands" (USDI/USDA 1977, p. 2-19). Comparisons of total fee and nonfee grazing costs on private and public lands are used to estimate the forage value on public lands that would make total grazing costs between the 2 land types equal. The total cost approach explicitly recognizes differences in non-fee grazing costs between private and public lands. Many of the differences in terrain, distance, and facilities are also implicitly considered in the cost comparison.

The total cost approach was used to derive the $\$ 1.23 \mathrm{AUM}^{-1}$ (Animal Unit Month) base rate used in the PRIA grazing fee formula (USDI/USDA 1977). Total fee and non-fee costs of grazing private and public rangelands were compared using data collected in a 1966 Western Livestock Grazing Survey (Little 1967, 1968; Houseman 1968). The $\$ 1.23 \mathrm{AUM}^{-1}$ difference in total grazing costs was considered to be the value of public land forage (USDI/USDA 1977). A major point of controversy was excluding interest on the permit investment as a cost item in calculating the base value.

The 1992 Incentive-Based Grazing Fee Study (Bartlett et al. 1993) also used the total cost approach as a forage valuation method. They started with the perception that the total cost approach would give an appropriate valuation of public land forage. The conclusion was that for total grazing costs to be equal on private and public lands, the public land grazing fee would have to be reduced from the 1992 level of $\$ 1.92 \mathrm{AUM}^{-1}$ to $\$ 0.13 \mathrm{AUM}^{-1}$. Cost differences were found between USFS and BLM permits and between cattle and sheep producers. The forage value for cattle grazing on BLM lands was $\$ 3.63$ $\mathrm{AUM}^{-1}$, but the value for cattle grazing USFS lands was $-\$ 2.86$ AUM $^{-1}$. The estimated forage value for sheep grazing was negative on both BLM and USFS lands. These values suggest, even without a graz- 
ing fee, sheep producers on both BLM and USFS lands, and cattle producers on USFS lands were paying more than those with private leases because of higher non-fee grazing costs.

These results are not consistent with the traditional profit-maximizing model that suggests livestock producers would not pay more to graze public lands than private land alternatives. Further, public land grazing permits will supposedly have grazing value only if total grazing costs on public lands are less than on private land. Yet, the observation is that public land grazing permits do have market value (Torell and Doll 1991, Rowan and Workman 1992, Sunderman and Spahr 1994, Spahr and Sunderman 1995, Torell and Kincaid 1996). Results imply that permit values currently occur without a cost advantage for grazing public lands. This may have changed over time. The traditional economic model explaining permit value apparently held reasonably well in the the 1960 s when major grazing fee studies were done to establish the PRIA grazing fee formula. Nielson and Wennergren (1970) found that capitalizing the average difference between total public and private grazing costs from the 1966 Western Livestock Grazing Survey, using an approximate $4 \%$ capitalization rate, equaled the average permit value. They concluded that competition and a free market existed for public land grazing permits. Average forage value estimates from their study supported the traditional belief at that time that permit values arise because of a capitalized cost advantage from public land grazing.

Private forage comparison methods fail to meet the profit-maximizing assumption about competitive markets and the derived demand for forage. The complementary value of public and private resources and the personal utility from ranching as a way of life are obvious examples of why ranchers pay more for public forage than livestock earning potential would justify (Bartlett et al. 1993).

Because the total cost approach has yielded inconsistent results through time and because repeating intensive studies to estimate non-fee grazing costs is expensive, additional grazing cost studies are not warranted. Grazing costs could be updated using an index of prices paid, similar to the Prices Paid Index used to update PRIA, but this indexing would not capture differences in the rate of change in grazing costs between private and public lands. Updating forage values could be done with an index similar to the Forage Value Index (USDA-NASS 2001), but this would ignore the inconsistencies found with the valuation procedure. Estimating livestock grazing cost differences between private and public lands does not recognize the Quality of Life (QOL) reasons for why ranchers are willing to pay as much as they do for both private and public forage.

\section{Permit Value Approach}

It is widely believed that the market value of grazing permits arises because grazing fees have been less than forage value. As noted by Roberts (1963), if forage markets are efficient, competition should equalize production costs by inflating ranch values by the capitalized value of any resource underpricing. Past underpricing and the capitalization of permit values have been described as the dilemma we now face in changing grazing fees (Workman 1988, Quigley and Thomas 1989, Torell and Fowler 1992). Past policies have not enabled the federal government to capture all of the benefits of public land grazing.

The underpricing of public land forage when given as the reason for grazing permits having value is largely justified on theoretical grounds, relating closely to the economic models formulated in Utah (Roberts 1963, Nielsen and Wennergren 1970). Empirical evidence, however, on the correlation between permit value and grazing fees is lacking. As noted by USDA/USDI (1992, p. 51), "There is no information on the correlation between the change in permit value and change in grazing fees." This is generally true, but 2 studies (using the same dataset) have found a correlation between ranch values and grazing fees. Torell and Doll (1991) used ranch sales data from New Mexico over the 1979-1988 period to estimate grazing permit values. Hedonic regression models were used to estimate how selected factors affected ranch values, including the apparent cost advantage for grazing on public lands. They estimated that, for every $\$ 1 \mathrm{AUM}^{-1}$ that public forage is priced below its apparent market value, the value of the ranch increased by $\$ 29.81$ $\mathrm{AUM}^{-1}$, which implies a $3.35 \%(1 \div$ 29.81) capitalization rate.

Using the Torell and Doll (1991) dataset, Xu et al. (1994) demonstrated how to correct a model misspecification by truncating allowable dependent variable estimates (land prices) at zero. With this adjustment, each $\$ 1 \mathrm{AUM}^{-1}$ of cost advantage on public lands increased ranch value by $\$ 40.45 \mathrm{AUM}^{-1}$, implying a $2.47 \%$ capitalization rate. In both the Torell and Doll (1991) and Xu et al. (1994) studies, the cost advantage variable was statistically significant at the $\alpha=0.05$ level. Other authors have relied on the $3.35 \%$ capitalization rate to estimate forage value (Torell et al. 1993, Sunderman and Spahr 1994, LaFrance and Watts 1995), but the adjustment suggested by $\mathrm{Xu}$ et al. (1994) means a capitalization rate of about $2.5 \%$ would be more appropriate. This lower rate of return is similar to the long-term average rate of return western ranchers have made from livestock production (Workman 1986).

The existence of permit value is well documented. Stern (1998) summarized 20 different studies that estimated permit value using various methods. These studies included capitalization of income (Gardner 1962, Lambert 1987); survey and professional opinion of ranchers, appraisers, and real estate brokers (Fowler and Gray 1980, Torell and Fowler 1985); appraisal of ranch sales that were nearly all federal land or where the permit was valued separately (Gardner 1962, Bartlett et al. 1993, USDA/USDI 1992, Salvo and Kerr 2001); and hedonic regression models (Rowan and Workman 1992, Spahr and Sunderman 1995, Torell and Kincaid 1996, Xu et al. 1994).

Permit value estimates range from negative amounts to $\$ 300 \mathrm{AUM}^{-1}$ (Stern 1998, USDA/USDI 1992, Sunderman and Spahr 1994). Permit values occur without an apparent grazing cost advantage on public lands (Bartlett et al. 1993), and a major part of this value appears to occur for reasons unrelated to livestock production and profit potential. Permit value estimates have been used to assign forage value for a combination of profit from livestock production and utility satisficing behavior (Bartlett et al. 1993). Implying that permit value is solely a capitalized value of excess livestock earning potential, as has traditionally been stated (Martin and Jeffries 1966, Torell and Doll 1991, Bartlett et al. 1993, Sunderman and Spahr 1994), is not appropriate.

The purchase of the grazing permit reflects an amount willingly paid in the competitive ranch real estate market. This value is in addition to the annual grazing fee. It implicitly considers purchaser expectations about future grazing fees, non-fee grazing costs, and land-use poli- 
cies, and gives an estimate of value irrespective of the multiple reasons for permit purchase. It captures the rancher's total willingness to pay for public land grazing. A drawback to using permit value to imply forage value is the need to select a subjective discount rate to convert capitalized permit value to annual forage value. Further, estimating hedonic ranch regression models requires detailed data defining ranch characteristics and terms of sale. Past studies in the western states have relied almost exclusively on data provided by Farm Credit Services appraisers. These data are limited or non-existent in some western states.

Estimating forage value using permit value is straightforward after recognizing that both livestock earnings potential and Quality of Life (QOL) values contribute to the value of the permit. Grazing permit value is the capitalized value of annual benefits from holding the lease. Thus, the annual value (A) can be estimated as $\mathrm{A}=i$ $\mathrm{x}$ permit value, where $i$ is the discount rate. This annualized value is added to the current grazing fee to estimate the annual value of public land forage (Roberts 1963).

Because grazing permits rarely sell independently of the base ranch, hedonic ${ }^{2}$ ranch value regression models have shown the greatest potential for estimating grazing permit values on a state or regional basis. The level of dependency on public lands varies widely, and federal and state grazing permits are transferable when ranches sell. Thus, an evaluation of ranch sales using hedonic regression models provides a way to estimate permit value regardless of the level of public land dependency. A more detailed description and discussion about hedonic ranch value model use to estimate grazing use values can be found in Bartlett et al. (2002).

Pope (1985) developed an hedonic land value model to evaluate factors that influenced rural land values in Texas. Pope used 1981 data from the Texas State Property Tax Board to estimate per acre expected annual returns for each land parcel studied. Quality of life (QOL) variables considered in the hedonic model included the number of white-tailed deer

\footnotetext{
${ }^{2}$ Economists and real estate analysts describe regressions of the price of a parcel of real estate as related to the characteristics of the real estate using the term "hedonic." Hedonic pricing models are built on the premise that goods traded in the market place have different bundles of attributes and characteristics that influence market value.
}

harvested per square mile, county population density, acres devoted to agriculture per square mile, highway mileage to various large Texas cities, and dummy variables defining regions of aesthetic appeal. As indicated by $\mathrm{R}^{2}$ values, Pope (1985) found only $14.7 \%$ of the per acre variation in rural Texas land values was explained by variation in annual returns, but the $\mathrm{R}^{2}$ value increased to $85.8 \%$ when QOL variables were included.

Hedonic models used to estimate the value of western ranches have varied from simple specifications to complex equations with numerous variables capturing differences in income-earning potential, location, time of sale, and Quality of Life (QOL) differences. Workman and King (1982) developed a very simple regression model where ranch price ( $\$$ cow unit $^{-1}$ ) was related to ranch size (number of cows), distance to markets, time of sale, the value of ranch improvements, and an adjustment for whether the sale included cattle. At the other extreme, Spahr and Sunderman (1995) and Torell and Bailey (2000) included over 20 variables in their hedonic regression models.

In estimating the value of western ranches, hedonic price models have been applied primarily in 2 western states Wyoming and New Mexico. Sunderman and Spahr (1994) and Spahr and Sunderman $(1995,1998)$ used Wyoming ranch sales data provided by Farm Credit Services (FCS) to estimate the market value of public land grazing permits and to study property tax inequities caused by the large disparity between livestock productive value and market value of Wyoming ranches. McLeod et al. (1999) used hedonic price models to study the market value of environmental amenities present on Wyoming ranches. Geographical Information System (GIS) data were used to visualize the scenic view at the centroid of a parcel of land and to quantify the abundance and quality of wildlife and fish habitat, as well as accessibility. Alternatively, Spahr and Sunderman (1995, 1998), Sunderman and Spahr (1994), and Rowan and Workman (1992) used a subjective assessment of scenic and recreation potential for each ranch and included this assessment as a dummy variable.

In New Mexico, Torell and various coauthors (Torell and Fowler 1986, Torell and Doll 1991, Xu et al. 1994, Torell and Kincaid 1996, Torell and Bailey 2000) have used hedonic price models to evaluate the determinants of ranch value. These hedonic models have consistently included percent of grazing capacity coming from public lands, time of sale, ranch size, rangeland productivity, house and building values, and cultivated acreage as explanatory variables. Torell and Bailey (2000) expanded the models to include aesthetic values by defining ranching area dummy variables where aesthetic values were expected to be higher because of mountainous terrain and desirable Quality of Life (QOL) characteristics. Other QOL variables have included distance to town (Pope 1985, Torell and Bailey 2000, Rowan and Workman 1992) and county population density (Pope 1985, Torell and Bailey 2000).

Hedonic models for estimating permit value appear to work well in the southwest where yearlong grazing is practiced. Similar research undertaken on seasonal ranges in Wyoming (Sunderman and Spahr 1994, Spahr and Sunderman 1995, 1998), resulted in inconsistent permit value estimates, with different permit values generated over time and between studies. Northern-state ranch value models do not seem to statistically fit the data as well as the yearlong grazing models appropriate for the southwest. Perhaps QOL values are more important and account for a larger share of ranch value in these northern states. If so, additional detail about the scenic and recreational characteristics and potential of each ranch studied, similar to the efforts of McLeod et al. (1999), will be needed to adequately explain the wide variation observed in ranch value and permit value for seasonally grazed ranches.

Using hedonic models developed for New Mexico, and survey data by Fowler and Gray (1980), the estimated nominal and real value of BLM, USFS, and New Mexico State Trust Land grazing permits in New Mexico from 1966 to 2000 are shown in Figure 1. The average value of deeded land is shown for comparison in those years when hedonic model estimates were available. Since about 1985 , the average real market value (inflation adjusted) of USFS and BLM permits in New Mexico have remained relatively constant at about $\$ 100 \mathrm{AUM}^{-1}$. Multiplying this value estimate by a 2.5 to $3.5 \%$ capitalization rate and adding the recent $\$ 1.35 \mathrm{AUM}^{-1}$ federal grazing fee suggests a nearly constant annual grazing value in the last 15 years of between $\$ 4$ and $\$ 5 \mathrm{AUM}^{-1}$. If $7 \%$ is considered to be the opportunity rate of return that ranchers forego by investing in grazing permits 

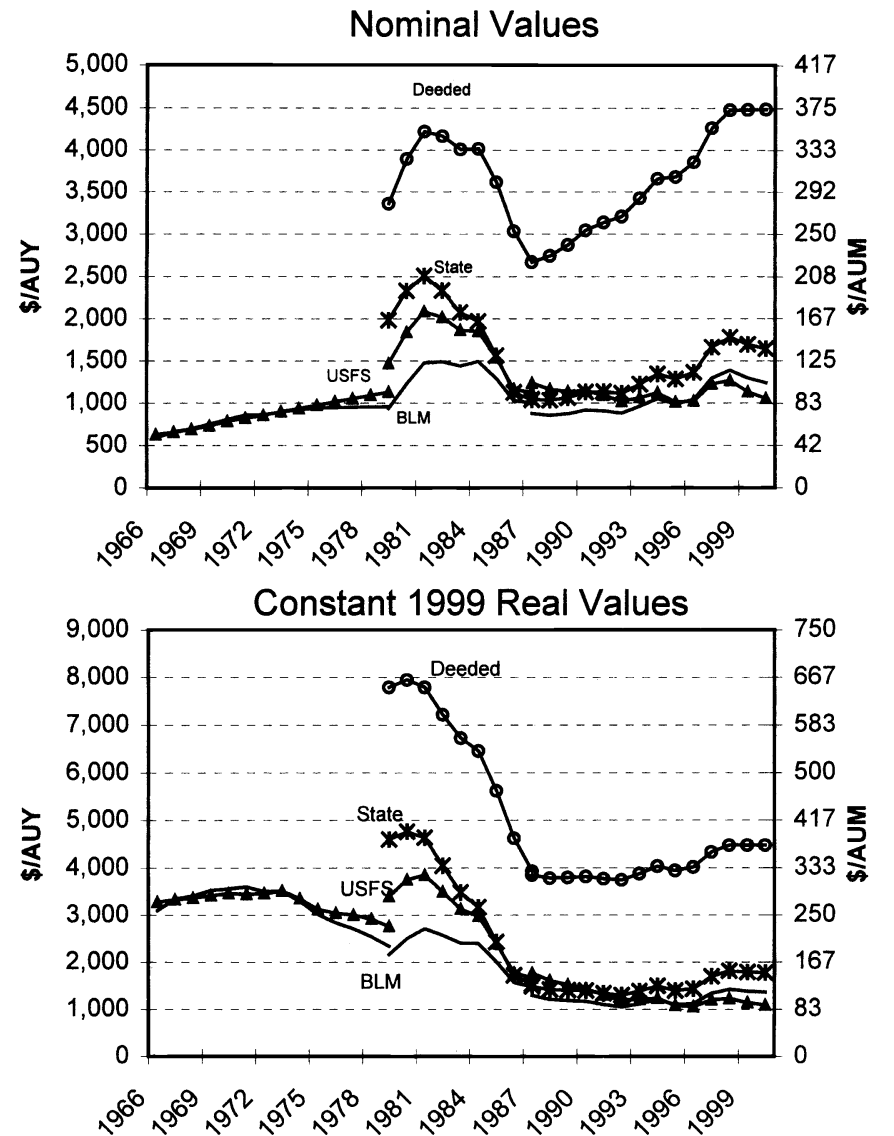

USFS, BLM, and State permit value estimates are not continuous because estimates were from different studies (Fowler and Gray 1980, Torell and Kincaid 1996, and Torell and Bailey 2000)

Fig. 1. Average nominal and real grazing permit values, and deeded land ranch values in New Mexico, 1966-1999 (From Torell et al. 2001).

(AAEA 1998), and used as the capitalization rate, the implied value of grazing is over $\$ 8 \mathrm{AUM}^{-1}$. As a regional comparison, recent estimates of average permit value in northern states, where seasonal grazing is common, have generally been between $\$ 35$ and $\$ 75 \mathrm{AUM}^{-1}$ (USDA/USDI 1992, Stern 1998), implying a lower forage value.

If a system is devised to use periodic permit value estimates to imply forage value across broadly defined areas (similar to that used by Bartlett et al. 1993), indexing could be used to provide annual updates until additional studies evaluate changes in permit value. Instead of the Forage Value Index (FVI), an index that tracks changes in asset values (e.g. land and buildings) over time could be developed to provide annual updates. Additional research would be needed to identify a preferred index and the components and weighting of the land value index. As demonstrated by the different trends in permit and deeded land values shown in Figure 1, an index of private agricultural land values may not be adequate, since public land policy and uncertainty about the future of grazing on public lands are additional factors affecting the value of public land grazing permits. There is no reason to believe the value of grazing permits will necessarily follow the trend of deeded land values, especially if grazing fees are significantly increased and grazing use continues to become more regulated and restrictive.

\section{Production Analysis and Linear Programming}

Various production analyses and budgeting techniques can be used to estimate the value of public land forage (Bartlett 1983). These procedures are linked to profit maximization, derived demand, and the value of forage for livestock production.

Using enterprise budgeting, the total gross value of ranch output is calculated and all costs except range forage are deducted. The remaining value is the residual return to the grazing resource. Dividing the residual return by the amount of forage yields the apparent per unit value of the unpriced forage input (Bartlett 1983).

Linear programming (LP) has been used to estimate forage value (Gee 1983, Kehmeier et al. 1987, Hahn et al. 1989) and to estimate economic impacts from changes in federal land policies (Peryman and Olson 1975, Bartlett et al. 1979, Torell et al. 1981, Gee 1981, Rowe and Bartlett 2001). The dual solution of an LP model provides an estimate of imputed prices for scarce resources, and this shadow price can be used as an indication of marginal value for rangeland forage and other scarce resources. As noted by Brokken and McCarl (1987), a resource shadow price is conceptually similar to Value Marginal Product (VMP) and factor demand. It is different in a strict theoretical sense because the optimal use of other inputs in the production process may change in the LP analysis, but are held constant when constructing VMP curves. The shadow price is affected by product prices, marginal productivity of inputs, and the prices of all inputs.

As an application to forage valuation, Gee (1981) and Hahn et al. (1989) used LP and resource shadow prices to estimate forage value on USFS and BLM lands. Shadow price estimates of forage value in 1981 were estimated to be $\$ 10.86 \mathrm{AUM}^{-1}$ for BLM and $\$ 11.58 \mathrm{AUM}^{-1}$ for USFS (Gee 1981). Hahn et al. (1989) updated Gee's work and reported shadow prices for each of 9 USFS regions and a national average. Values ranged from $\$ 9.22 \mathrm{AUM}^{-1}$ in Region 3 (New Mexico and Arizona) to $\$ 15.11 \mathrm{AUM}^{-1}$ in Region 5 (California).

Problems have been noted in using shadow prices for resource valuation. Most notably, different shadow prices can be obtained by including different formulations of the constraint set. What costs and where they are included in the objective function also have an impact on shadow price levels. The shadow price estimates of value reported by Gee (1981) measured the return above cash costs per AUM. When depreciation costs and the value of family labor were considered, forage value estimates decreased to $\$ 6.61$ $\mathrm{AUM}^{-1}$ and $\$ 7.05 \mathrm{AUM}^{-1}$ for BLM and USFS, respectively. Hahn et al. (1989) performed additional analyses in which fixed costs and opportunity costs were subtracted from the objective function to estimate long-run shadow prices. These 
estimates averaged $\$ 0.49 \mathrm{AUM}^{-1}$ when family labor, interest on investment, and capital replacement were included as cost items in the LP model.

The difference in short- and long-run shadow prices reported by Hahn et al. (1989) is an example of the differences in shadow prices that can be obtained when the objective function is altered. As noted by Godfrey and Nielsen (1994), it conceptually does not matter whether non-fee grazing costs are included in the Linear Programming (LP) model as a cost to raise a cow or added to the cost of grazing a particular forage resource. Each cow raised will require forage, and non-fee costs can be considered under the "cow-raising" activity or added as a non-fee expense to the "forage-harvesting" activity. The only conceptual problem is to assure that nonfee forage-harvesting costs are counted but not double counted. Godfrey and Nielsen (1994) demonstrated that shadow prices for forage depended on the allocation of non-fee costs between the forage-harvesting and livestock-raising activities.

A wide range of forage values can be justified depending on the parameter definitions of the LP models. Further, given the wide differences in production strategies, resources, and the economic position of western ranches (Gentner 1999), it is likely that numerous models and scenarios would be required to determine forage values from production analysis.

Estimating forage values using production analysis tools, like enterprise budgeting and ranch-level linear programming models, suggests forage value arises only because of livestock production potential. Quality of Life (QOL) values are ignored and the true value of grazing use on public lands will be underestimated. In addition, the expense of building production economic models (generally based upon primary data collection) and breadth of coverage (state or regional) limit their applicability in defining the value of grazing use on public land. Only if the policy or research objective was to determine the value of forage for livestock production would this approach be appropriate.

\section{Competitive Bidding}

Establishing a market for public land forage through a competitive bid system has strong theoretical appeal because the forces of supply and demand would define forage value (Gardner 1962, 1963, Martin and Jeffries 1966, Nielsen 1972,
USDI/USDA 1977, USDA/USDI 1992). However, the option of moving to a competitive bid system has been repeatedly rejected by the federal agencies. They believe it would be disruptive to the stability of permittees and rural communities dependent upon public land forage and would not be manageable given the isolated and scattered nature of many public land grazing permits, especially with current permit structure, regulations, and staffing (USDI/USDA 1977, 1993 USDA/USDI 1992).

Competitive bidding for public land forage is done on a very limited basis. For example, forage is leased on a competitive bid basis at the McGregor Bombing Range in southern New Mexico and at Fort Meade in South Dakota (USDA/USDI 1992). Fowler et al. (1994) found that annual bid rates for the McGregor Bombing Range varied greatly depending on rangeland conditions in west Texas and eastern New Mexico. When forage was depleted on area ranches, bidding and bid amounts increased.

If forage is demanded for a combination of profit potential and utility-satisfying behavior, a competitive bid process could be used to determine the market value of public land forage, regardless of the specific motives of the lease participants. Under a competitive bid system, a process would be developed to solicit open, competitive bids for grazing rights on an annual or multi-year basis. If this approach were used, there would be no need to develop an updating mechanism because a market for public land forage would be created and market-clearing prices would be determined through the bidding process. If not all public lands could be competitively leased because of the small or scattered nature of some permits, indexing or average valuation of those that did lease could be used to value those that were not competitively leased or priced.

\section{Contingent Valuation}

The contingent valuation method (CVM) has been used to value many different goods, most commonly aesthetic and environmental improvements and recreational activities (Carson et al. 1996, Van Kooten and Bulte 2000). The CVM uses surveys to elicit information about the maximum amount an individual would be willing to pay (WTP) for an amenity or the minimum amount an individual would be willing to accept (WTA) to forgo con- sumption of an amenity. Theoretically, CVM analysis examines this tradeoff in light of an individual's underlying utility function $(u)$. Following An (2000), a person's WTP for an amenity, offered at a fixed level, is defined as the dollar amount $Y$ that equalizes two indirect utilities such that $V_{1}(I-Y \mid Z, \varepsilon)=V_{0}(I \mid Z, \varepsilon)$ where, $V_{1}$ and $V_{0}$ are the individual's indirect utility with and without the amenity, respectively, $I$ is the individual's disposable income, $Z$ is a vector of observed demographic and other characteristics, and $\varepsilon$ is a scalar variable representing unobserved personal characteristics. Given the assumption that $V_{1}$ is monotonically increasing in $u$ for any fixed $(Z, \varepsilon)$, an inverse utility function exists such that $U\left(V_{1}(u \mid Z, \varepsilon) ; Z, \varepsilon\right)=u$ for all $u \geq 0$. WTP can then be expressed as $Y$ $=I-U\left(V_{0}(I Z, \varepsilon) ; Z, \varepsilon\right)$. Using CVM, $Y, Z$, and $I$ can be elicited from members of a selected population and their WTP assessed by econometric techniques.

While the majority of contingent valuation studies have attempted to value nonmarket goods, contingent valuation has also been used to value goods traded in markets (Harrison 1989, Kahneman and Knetsch 1992) or quasi-markets (Hof et al. 1989, Carson et al. 1996). Although contingent valuation was originally designed to elicit estimates of use value, recently the emphasis has been on eliciting nonuse values, such as existence values and bequest values (Jakobsson and Dragun 1996).

Contingent valuation is not without its weaknesses in being able to elicit a person's WTP or WTA. The methodology suffers from the same potential biases that are prevalent in survey research, such as interviewer bias and nonresponse bias. But the 2 major concerns with CVM are hypothetical bias and strategic bias. Some researchers contend that a fundamental difference exists between the way an individual makes a hypothetical decision and an actual decision (Neill et al. 1994). Hypothetical bias results from the inability of respondents "to accurately predict how they would behave if a market were created" (Bishop and Heberlein 1990, p. 92). Respondents' understanding of the circumstance or amenity they are asked to value may be limited or imprecise. Individuals may find it difficult to express their value for, or feelings about, an amenity in monetary terms. If respondents rely on a starting bid price presented in the Contingent Value Method (CVM) instrument as an indication of what the value of the amenity should be, starting-point bias 
can result (Bishop and Heberlein 1990).

The desire to intentionally mislead the researcher in order to influence policy has been termed strategic bias (Jakobsson and Dragun 1996). Individuals may express an unrealistically high willing to pay (WTP) if they believe they will not actually have to make the payment, yet believe they can influence the desirable supply of the amenity in question by giving a high value. Conversely, they may understate the true value if they feel it will decrease the amount they will have to pay (Bishop and Heberlein 1990).

Contingent Value Method (CVM) is dependent upon primary data gathered through phone or mail surveys, and the data collection expense is high. Given the expense of generating these values, indexing values determined at a point in time appear to be the only possible way of updating values.

In their review of grazing fees and public land management, Rostvold and Dudley (1992) suggested that CVM be used to impute the economic value derived from public land grazing. To date, Hof et al. (1989) has been the only CVM study attempting to elicit WTP for grazing on federal lands. They applied CVM in 4 different formats to value public land forage. Two formats elicited ranchers' willingness to pay, and two examined their willingness to sell. All questions were "open-ended" wherein respondents were asked to fill in a dollar amount representing a maximum willingness to pay or minimum willingness to accept compensation. By comparison, a closed-ended format asks for yes or no responses to a specified dollar amount. Open-ended questions are thought to eliminate starting-point bias. An open-ended format does not offer the respondent information regarding the potential value of the amenity, but allows the individual to devise their maximum willingness to pay or minimum willingness to sell (Bishop and Heberlein 1990).

The price-response formats of the Hof et al. (1989) survey, where respondents were asked their WTP or willing to accept (WTA) in dollar terms, tended to result in either the current federal grazing fee or the private lease rate. This would appear to indicate that respondents were very familiar with the grazing fee issue and might have biased their response on expected outcomes. Quantity-response formats, where respondents were asked to respond to changes in grazing fees in terms of number of cattle they would graze, result- ed in all or nothing bids; they would respond with either the current number of cattle they grazed or they would respond that they would not graze any cattle.

Using Contingent Value Method (CVM ) to value goods, such as public land grazing, may result in biased responses by users who are dependent on the good for their livelihood. Because of this apparent response bias, Hof et al. (1989) concluded that CVM would be an inappropriate way to value public land forage. We feel, however, that CVM may still be a valuable methodology in examining the production and Quality Of Life (QOL) values associated with public land grazing, given recent advances in CVM and a new design of survey methods.

Many of the problems associated with CVM could potentially be rectified by appropriately defining the policy issue to be addressed. Hof et al. (1989) showed that using the grazing fee as the payment vehicle created a strategic bias by respondents. Mitchell and Carson (1987) suggested the payment vehicle must be both realistic and neutral. While the grazing fee is a realistic payment vehicle for federal forage, it is not neutral given the political controversy that surrounds grazing fees. Permit value might be a viable alternative as the payment vehicle. Federal land permittees have argued for decades that permit value is a legitimate cost of grazing on federal lands. Most ranchers purport that permits have value and have been willing to give an estimate of their worth. Asking the question in terms of willingness to pay for a grazing permit, as a one-time payment as opposed to an annual payment, could reduce bias and the direct correlation to the annual grazing fee observed by Hof et al. (1989). One could also ask about Willing To Pay (WTP) for adding to the amount of grazable land or AUMs covered by the permittee's current allotment.

One of the problems associated with using permit value as the payment vehicle in a CVM study is asking the valuation question in a realistic manner. Grazing permits represent a privilege to graze federal forage and are tied to a base ranch property, such as deeded acreage, water rights, and/or livestock. Grazing permits are typically transferred by the agency to another owner when the base property exchanges hands. Therefore, it is important to embed the valuation question in a setting that is both realistic and legal.

Willingness to pay questions are typically used in contingent valuation studies because of the difficulty in obtaining valid willingness to accept compensation results (Jakobsson and Dragun 1996). Individuals typically have difficulty accepting a compensation scenario when dealing with natural resource issues (Mitchell and Carson 1987). Empirical studies have shown that willingness to accept values are typically 3 to 20 times more than those obtained from willingness to pay questions (Jakobsson and Dragun 1996). Mitchell and Carson (1987) suggested that willingness to accept measures are appropriate if the agent has the right to sell the good in question. With most natural resource assets, the common citizen does not have a vested property right in the good being examined. Conversely, ranchers have been able to transfer grazing permits to others, with the permit being capitalized in the total value of the ranch, implying some level of real or perceived property right. Hence, it might be possible to ask Willing To Accept (WTA) questions in terms of giving up some or all grazable land covered by an existing grazing permit. Testing the experimental design with appropriate focus groups should show if one measure provides better results.

\section{National and Regional Forage Values}

One element of the controversy about grazing fees is the belief that forage values throughout the West should be different because of forage type, location, level of range improvement, and a number of other factors. Many believe that, rather than one forage value for all public lands there should be multiple forage values determined by site-specific factors (Robertson 1978, LaFrance and Watts 1995).

For many years, Forest Service grazing fees were based on surveys of comparable private rangeland used to derive forage values on Forest Service rangeland. These values varied by state, national forest, and, in some cases, ranger districts within a forest (Rachford 1924). After 1931, these values were updated by relative changes in livestock markets from base periods of 1921-1930 for cattle allotments and 19201932 for sheep (Dutton 1953). Prior to 1968, the USFS had 19 different base grazing fee rates for cattle and 17 for sheep on the western national forests (Nielsen 1972). 
In 1969, the USFS and BLM established a nationally uniform grazing fee that was to be implemented over a 10 -year period. Prior to completion of the 10-year period, the Public Rangeland Improvement Act (PRIA) was passed by Congress and a new fee schedule established for 1979. The uniform fee policy was based on recommendations from a Western Livestock Grazing Survey (Little 1967, 1968, Houseman 1968) that found total grazing cost (fee and non-fee) differences between ranching areas were not large in relation to differences within ranching areas. The authors concluded that, given the large variability in grazing costs and forage values, one national value for public land forage was justified.

This conclusion was in contrast to Robertson (1978) and others who believed forage values had to vary in different areas of the West and argued for variable fees based on range quality differences. But as noted by Nielsen $(1972$, p.5), "Many people believe that forage quality should play a vital role in determining grazing fee levels, i.e., the higher the quality and quantity of forage per acre, the higher the fee per AUM. The data available (grazing cost survey data) do not support this notion." Calculating lease rates on a forage quantity basis $\left(\$ \mathrm{AUM}^{-1}\right)$ eliminated differences observed on a quantity-per-acre basis.

Other researchers have also failed to find significant differences between regions based on cost-of-production studies, largely because of extreme variation in observed grazing costs both within and between regions. Bartlett et al. (1993) and Van Tassell et al. (1997) reported on a comprehensive assessment of grazing costs and forage values estimated across broad ecological regions (Great Plains, Northern Rocky Mountains, Inter-mountain/Columbia Plateau, and others) in Idaho, New Mexico, and Wyoming. These authors found as much variation in grazing costs and forage values within the 12 ecological regions included in the 3 states as between them. They concluded that one national value was justified because statistically valid regions could not be defined.

Several researchers have justified variable grazing fees based upon stratification of ranch sales and/or private lease rates. Spahr and Sunderman (1995) examined Wyoming ranch sales and found that in the Wyoming real estate market grazing permits were valued differently between eco- logical regions and by type of lease. Similarly, permit values have generally been found to be lower in the seasonal grazing northern states, as compared to Arizona and New Mexico where yearlong grazing is common (Bartlett et al. 1993). Thus, the permit valuation method suggests that annual forage values are lower in the northern states.

LaFrance and Watts (1995) found private lease rate differences among states. They argued that because of these differences, forage values and grazing fees on public lands should also differ by state. They suggested separating the western region into 3 areas for the purposes of calculating forage values on public lands: 1) Arizona, California, and New Mexico; 2) Colorado, Montana, and Wyoming; and 3) Idaho, Nevada, Oregon, Utah, and Washington. Tittman and Brownell (1984) used appraisal techniques to delineate 6 separate pricing areas in the western U.S., based on observed differences in grazing lease rates and other lease provisions. Fowler et al. (1986) used this same data set for New Mexico and suggested 3 separate pricing regions for New Mexico.

Van Tassell and McNeley (1997) also found evidence that private lease rates were statistically different between states in the western region. They used regression techniques to estimate the major factors influencing private lease rates and found these to be lagged yearling price, current year hay price, lagged lease rates, and current input costs. Areas suggested by their analysis included: 1) Washington, Oregon, Idaho, and Utah; 2) Montana, Wyoming, Colorado, Nevada, and California; and 3) Arizona and New Mexico.

Applying the total cost approach to private grazing leases yielded similar variable results. Rimbey et al. (1994) summarized the non-fee costs of grazing on 134 private leases in Idaho, New Mexico, and Wyoming. This study found that New Mexico private grazing costs were statistically greater than those in Idaho and Wyoming.

Perhaps the main conclusion that can be drawn about regional forage values is that they are extremely variable, both within and between states and regions. Houseman (1968) emphasized that cost differences found between allotments should be interpreted as the actual situation and not as an indication of inaccurate data. There is an extreme amount of variation in what people pay to lease forage, and much of this difference has nothing to do with the value of the forage for livestock production. An obvious implication is that only a competitive market can capture the value of forage on each specific allotment. Further, only those valuation procedures that can capture both livestock production value and Quality of Life (QOL) values can potentially estimate regional differences in the willingness to pay for forage and grazing use on public lands.

\section{Summary and Conclusions}

Many forage value studies in the last 40 years have resulted in low or negative estimates of public land forage value. Livestock production returns are low when compared to any standard investment criteria. Yet ranchers still graze livestock on public lands and purchase ranches with grazing permits. We have come to realize that public land forage values include not only traditional livestock production values but also other quality-of-life values, a point that Martin and Jeffries (1966) made over 30 years ago.

Most studies about the value of public land forage have focused on the traditional value of rangeland forage for livestock production. The most common methods used since the original USFS forage value study in 1916 have been the market price comparison and the total cost approach. Production analysis has been used in the last 20 years, particularly to estimate impacts of changes in federal rangeland policies.

Any method of valuing public land forage should incorporate both livestock production value and Quality Of Life (QOL) market influences if the total willingness to pay for public land grazing is to be estimated. This eliminates the use of the total cost and production analysis methods as justifiable public land forage valuation techniques, because they consider only livestock production value. Public land ranchers have demonstrated their willingness to pay more than this value by paying nearly equal total grazing costs (fee and non-fee costs) and additionally purchasing public land grazing permits.

The market price comparison method has traditionally been applied as if forage value arises only from livestock earning potential, but, as noted by Martin and Jeffries (1966), the private forage market also captures other QOL values. To use 
private land lease rates as an indication of public forage value requires major adjustments for differences in lease conditions and terms between private and public land leases. The validity of the adjustments will always be questioned and controversial.

Competitive bidding has been proposed as a method to capture the full value of public land grazing (Gardner 1962), but because this method is limited by practical and political concerns about disrupting rural communities and the fairness to current leaseholders, we believe it is not a viable option for all public land parcels. Larger public land parcels could be competitively leased when sufficient competition for the lease exists. Average lease prices for these parcels could then be used to set grazing fees for other parcels that could not be competitively leased because of land-locked location, their scattered nature, or lack of bids.

The permit value approach was originally developed to explain the difference between grazing fees and the apparent market value of public land forage (Roberts 1963). Even as traditional methods, such as the total cost approach used by the 1993 Incentive-Based Grazing Fee study, estimated low values for forage, the permit value approach still resulted in reasonable values. As this was occurring, other research was corroborating Smith and Martin's (1972) declaration that the economic profit motive was only one reason people own ranches and pay what they do for forage.

We believe 2 valuation approaches, Contingent Value Method (CVM) and hedonic regression models, have the most potential for estimating the full market value of public land forage, but these methods require additional refinement, application and testing. While CVM has not been successfully applied to forage valuation studies, it may have the potential to assess the total value or willingness to pay for public land grazing, provided respondents do not associate the valuation with grazing fees and correspondingly provide biased answers. Permit value captures the excess value public land ranchers are willing to pay for public land grazing. It theoretically provides a site-specific estimate of value that incorporates the specific characteristics (e.g., distance, terrain, level of improvement, grazing cost structure, scenic attributes) of each individual allotment. However, permit value is not directly observable in most cases because the value of grazing permits is capitalized into the total value of the ranch. Hedonic regression models, or the observed value when grazing permits trade without other deeded lands, are required to separate the permit value component.

Significant policy implications arise when the primary reason for ranch ownership and livestock production is not profit. Whittlesey et al. (1993) expounded on some of these implications after noting the same inconsistencies in past forage valuation attempts:

"Extensive cost-of-grazing studies have shown that ranchers, on average, are currently spending as much per unit of forage on public lands (current fees plus costs of use travel, herding, salting, and so on) as is paid for forage on private lands. Economic theory suggests, therefore, that the value of permits for grazing public lands should be zero, but that is not the case. This leaves some troubling possibilities: our economic models are wrong, ranchers are not profit maximizers, or ranchers benefit from more than forage through the use of the grazing permits. One obvious suggestion does emerge, however. We should cease attempts to discover the 'fair market value' of grazing on public lands for setting the optimal grazing fee and focus our attention on more important and productive issues. Not only is the fair market value of the forage difficult to establish without a bidding process, but it is not the most relevant issue to guide the fee structure for public land grazing." (p. 16).

We agree with nearly all of the points made by Whittlesey et al. (1993). When ranch market values are driven by nonprofit factors, disparities will exist between the livestock production value and market value of forage. Traditional profit-maximizing models used to evaluate land-use policies will be wrong (or at least incomplete) for determining the value of grazing use. Ranchers do benefit from more than forage by holding public land grazing permits. The value of forage (or total willingness to pay for forage) will be hard to estimate without an established forage market and the traditional assumption about profit maximization. However, we do not conclude, as Whittlesey et al. (1993) did, that the implication is that we should give up on attempts to estimate forage value. We stick with our earlier con- clusion that "Additional attempts to define the market value of public land grazing using market price comparisons are not justified" (Bartlett et al. 1993, p. iv), but we believe the economic value of public land forage is an important question to answer. In addition to the obvious application to grazing fees, forage value is needed for evaluating the economics of range improvements, resource value comparisons, and in impact assessments as public land forage is allocated to other uses. There certainly is validity, however, to the major point of Whittlesey et al. (1993) that grazing use of public lands would be more acceptable if the value of grazing exceeded the costs of managing grazing activity and protecting other public values on public rangelands. By using valuation methods that consider all benefits derived from public land grazing, correct benefit/cost assessments of public land grazing can be made.

\section{Literature Cited}

Adkins, W.G., and K.E. Graeber. 1978. Market value versus use value of agricultural land in Texas. Paper No. R-178-1M-115. Texas Real Estate Res. Center, College Station, Tex.

American Agricultural Economics Association (AAEA). 1998. A report of the AAEA task force on commodity costs and returns. Iowa State Univ., Ames, Iowa.

American Society of Farm Managers and Rural Appraisers (ASFMRA) and Appraisal Institute (AI). 2000. The appraisal of rural property. ASFMRA/AI publishers.

An, M.Y. 2000. A semiparametric distribution for willingness to pay and statistical inference with dichotomous choice contingent valuation data. Amer. J. Agr. Econ. 82:487-500.

Barkema, A. and N. Novack. 2000. The farm slump eases. Federal Research Bank of Kansas City, Econ. Rev. $4^{\text {th }}$ Quarter:37-49. Available online at http://www.kc.frb.org.

Bartlett, E.T. 1983. Valuing range forage on public rangelands. In: F.J. Wagstaff (ed), Proc.: Range Econ. Symposium and Workshop, Aug. 31-Sept. 2, 1982, Salt Lake City, Utah. USDA Forest Serv. Gen. Tech. Rep. INT-149. pp. 92-99.

Bartlett, E.T., R.G. Taylor, and J.R. McKean. 1979. Impacts of federal grazing on the economy of Colorado. A Report to the U.S. Forest Serv., Bur. of Land Manage., and the Colo. State Agr. Exp. Sta., Fort Collins, Colo.

Bartlett, E.T., R.G. Taylor, J.R. McKean, and J.G. Hof. 1989. Motivations of Colorado ranchers with federal grazing permits. J. Range Manage. 42:454 457.

Bartlett, E. T., L. A. Torell, N. R. Rimbey, L. W. Van Tassell, and D. W. McCollum. 2002. Methodological issues in valuing of Forest Service grazing and range use. USDA Forest Serv. General Tech. Rep RMRS-GTR(in press). 
Bartlett, E.T., N.R. Rimbey, L.A. Torell, L.W. Van Tassell, J. Devilbiss, R. Appel, T. Heisler, G. Stoebig, T. Bagwell, P. Burgener, and J. Coen. 1993. The Federal Grazing Fee: 1993, Part I. In: Incentive-based grazing fee system for public rangeland administered by the Bur. of Land Manage. and the U.S. Forest Serv. USDI-BLM/USDAUSFS, Washington, D.C.

Becker, G.S. 1965. A theory of the allocation of time. Econ. J. 75:493-517.

Bishop, R.C. and T.A. Heberlein. 1990 The contingent valuation method. In: E.T. Johnson and G.V. Johnson. (eds.). Econ. valuation of natural resources: issues, theory, and applications. Westview Press. Boulder, Colo.

Biswas, B., J.R. Lacey, J.P. Workman, and F.H. Siddoway. 1984. Profit maximization as a management goal on southeastern Montana ranches. West. J. Agr. Econ. 9:186-194.

Brokken, R.F. and B.A. McCarl. 1987. A theoretical evaluation of fee systems for private grazing on federal lands. Rep. No. 570. USDA, Econ. Res. Serv., Washington, D.C.

Carson, R.T., N.E. Flores, K.M. Martin, and J.L. Wright. 1996. Contingent valuation and revealed preference methodologies: comparing the estimates for quasi-public goods. Land Econ. 72:80-99.

Dudley, T.J. and G.N. Rostvold. 1992. New perspectives on grazing fees and public land management in the 1990's. Part II: A scientific evaluation and critique of the 1986 and 1992 grazing fee studies. Rep. to Congress, Pepperdine Univ., Grad. School of Business and Manage.

Dutton, W.L. 1953. History of Forest Service grazing fees. J. Range Manage. 6:393-398.

Fowler, J.M. and J.R. Gray. 1980. Grazing land values in New Mexico. N.M. State Univ. Agr. Exp. Sta. Research Rep. No. 456., Las Cruces, N.M.

Fowler, J.M., M. Blake, and L.A. Torell. 1986. Heterogeneity of data: implications for a variable federal grazing fee. J. Range Manage. 39:194-196.

Fowler, J.M., L.A. Torell, and G. Gallacher 1994. Competitive pricing for the McGregor Range: implications for federal grazing fees. J. Range Manage. 47:155-158.

Fowler, J.M., L.A. Torell, J.M. Witte, and R.D. Bowe. 1985. Private land grazing transactions in New Mexico, 1983-1984, implications for state trust grazing fees. Range Improvement Task Force Rep. 18. N.M. State Univ., Las Cruces, N.M.

Gardner, B.D. 1962. Transfer restrictions and misallocation of livestock grazing permits. J. Farm Econ. XLIV:50-63.

Gardner, B.D. 1963. A proposal to reduce misallocation of livestock grazing permits. J. Farm Econ. 45:109-120.

Gee, C.K. 1981. Estimating economic impacts of adjustments in grazing on federal lands and estimating federal rangeland forage values. Tech. Bull. 143. Colo. State Univ. Agr. Exp. Sta., Fort Collins, Colo.

Gee, C.K. 1983. The use of linear programming to estimate range forage values. In: F.J. Wagstaff (ed), Proc.: Range Econ. Symposium and Workshop, Aug. 31-Sept. 2, 1982, Salt Lake City, Utah. USDA Forest Serv. Gen. Tech. Rep. INT-149. pp. 89-91.
Gentner, B. 1999. Characteristics of public land grazing permittees. Masters Thesis, Ore. State Univ. Corvallis, Ore.

Godfrey, E.B. and D.B. Nielsen. 1994. Shadow prices for forage on western rangelands: a methodological comment. pp. 21-26. In: N.R. Rimbey and D.E. Isaak (eds.). Current issues in rangeland economics - 1994: a series of papers written by members and associates of Western Res. Coordinating Committee 55 Range Econ. A Western Regional Res. Pub. Univ. of Ida., Agr. Exp. Sta., Moscow, Ida.

Gray, J.R., J.M. Fowler, and L. Foster. 1983. Grazing leases on private rangelands and implications for public lease fees. N.M. State Univ. Agr. Exp. Sta. Res. Rep. 487. Las Cruces, NM.

Hahn, W.F., T.L. Crawford, K.E. Nelson and R.A Bowe. 1989. Estimating forage values for grazing National Forest lands. Commodity Econ. Div., Econ. Res. Serv., USDA, Staff Rep. No. 89-51.

Harper, W.L. and C. Eastman. 1980. An evaluation of goal hierarchies for small farm operators. Amer. J. Agr. Econ. 62:742-747.

Harrison, G.W. 1989. Theory and misbehavior of first-price auctions. Amer. Econ. Rev. 79:749-762

Hof, J.G., J.R. McKean, R.G. Taylor, and E.T. Bartlett. 1989. Contingent valuation of a quasi-market good: an exploratory case study of federal range forage. USDA Forest Serv. Res. Paper RM-283.

Houseman, E.E. 1968. Special report on the grazing fee survey. Unpublished report. USDA Stat. Rep. Serv. 29 Nov. 1968. Washington, D.C.

Jakobsson, K.M. and A.K. Dragun. 1996. Contingent valuation and endangered species: methodological issues and applications. Edward Elgar Publishing Company. Brookfield, Vt.

Jensen, B.C. and D. Thomas. 1967. Determining grazing fees on National Forests. Rep. 9. Committee on Econ. of Range Use and Development of West Agr. Econ. Res. Counc., Utah State Univ., Logan, Ut.

Kahneman, D. and J.L. Knetsch. 1992. Valuing public goods: the purchase of moral satisfaction. J. of Enviro. Econ. and Manage. 22:57-70

Kearl, G. 1989. Critical review of federal graz ing fee studies. Rep. No. B-930. Univ. of Wyo. Agr. Exp. Sta., Laramie, Wyo.

Kehmeier, P.N., T.M. Quigley, R.G. Taylor, and E.T. Bartlett. 1987. Demand for Forest Service grazing in Colorado. J. Range Manage. 40:560-564.

LaFrance, J.T. and M.J. Watts. 1995. Public grazing in the West and "Rangeland Reform '94.' Amer. J. Agr. Econ. 77:447-461.

Lambert, D.K. 1987. Ranch values and the federal grazing fee. J. Range Manage. 40:397400.

Lancaster, K.J. 1966a. A new approach to consumer theory. J. of Political Econ. 74:132-157.

Lancaster, K.J. 1966b. Change and innovation in the technology of consumption. Amer. Econ. Rev. 56:14-23.

Liffman, R.H., L. Huntsinger, and L.C. Forero. 2000. To ranch or not to ranch: home on the urban range. J. Range Manage. 53:362-370.

Little, Arthur D.I. 1967. An analysis of western livestock grazing costs. A report to U.S. Dep. of Interior. Rep. No. 69463

Little, Arthur D.I. 1968. A multivariate analysis of livestock grazing costs. A report to U.S. Dep. of Interior. Rep. No. 69781.

Martin, W.E. 1966. Relating ranch prices and grazing permit values to ranch productivity. J. Range Manage. 19:248-252.

Martin, W.E., and G.L. Jeffries. 1966. Relating ranch prices and grazing permit values to ranch productivity. J. Farm Econ. 48:233-242.

McGrann, J.M. 2000. Cow-calf SPA key measures summary for the Southwest, 1991- 98. In: Integrated Resource Management (IRM) commercial cow-calf SPA handbook educational material. Texas Agr. Ext. Serv., College Station, Tex.

McLeod, D.M., C.T. Bastian, M.J. Germino, W.A. Reiners, and B.J. Blasko. 1999. The contribution of environmental amenities to agricultural land values: hedonic modeling using geographic information systems data. Selected Papers of Western Agr. Econ. Assoc. Annu. Meeting, Fargo, N.D., July $11-14$, 1999. Agr. Econ Res.: Res. in Agr. and Applied Econ. http://agecon.lib.umn.edu/waea97.html.

Mitchell, R.C. and R.T. Carson. 1987. Using surveys to value public goods: the contingent valuation method. Resources for the Future. Washington, D.C.

Neill, H.R., R.G. Cummings, P.T. Ganderton, G.W. Harrison, and T. McGuckin. 1994. Hypothetical surveys and real economic commitments. Land Econ. 70:145-154.

Nielsen, D B. 1972. Economic implications of variable versus single grazing fees. J. Range Manage. 25:2-6.

Nielsen, D.B. and E.B. Wennergren. 1970. Public policy and grazing fees on federal lands: some unresolved issues. Land and Water Law Rev., Univ. of Wyo. 5:293-320.

Peryman, J.S. and C.E. Olson. 1975. Impact of potential changes in BLM grazing policies on west-central Wyoming cattle ranches. Univ. of Wyo. Agr. Exp. Sta. Res. J. 87. Laramie, Wyo.

Pope, C.A. 1985. Agricultural productive and consumptive use components of rural land values. Amer. J. Agr. Econ. 67:81-86.

Quigley, T.M. and J.W. Thomas. 1989. Range management and grazing fees on the National Forests. Rangelands. 11:28-32.

Rachford, C.E. 1924. Range appraisal report. Unpublished report prepared for the Secretary of Agriculture, USDA, Forest Serv., Washington, D.C.

Rimbey, N.R., R. Krebill-Prather, and J.E. Carlson. 1992. Range and pasture forage: what's it worth? Res. Ser. No. 92-3. Univ. of Ida., Agr. Exp. Sta., Moscow, Ida.

Rimbey, N.R., L.A. Torell, E.T. Bartlett, and L.W. Van Tassell. 1994. Private grazing lease arrangements and their application to market price comparisons. J. Amer. Soc. Farm Manage. and Rural Appraisers. 58:125-129.

Roberts, N.K. 1963. Economic foundations for grazing use fees on public lands. J. Farm Econ. 45:721-731. 
Roberston, J.H. 1978. The grazing fee as an incentive for range management. Rangeman's J. 5:19-21.

Rostvold, G.N. and T.J. Dudley. 1992. New perspectives on grazing fees and public land management in the 1990's, Part I-an agenda for the 1990's. Rep. to Congress, Pepperdine Univ., Grad. School of Business and Manage.

Rowan, R.C. and J.P. Workman. 1992. Factors affecting Utah ranch prices. J. Range Manage. 45:263-266.

Rowe, H.I., and E.T. Bartlett. 2001. Development and federal grazing policy impacts on two Colorado counties: a comparative study. In: L.A. Torell, E.T. Bartlett, and R. Larranaga (eds.). Current issues in rangeland resource economics: Proc. of a symposium sponsored by Western Coordinating Committee 55 (WCC-55), N.M. State Univ., Res. Rep. 737, Las Cruces, N.M.

Rowe, H.I., E.T. Bartlett, and L.E. Swanson, Jr. 2001. Ranching motivations in two Colorado counties. J. Range Manage. 54:314-321.

Salvo, M. and A. Kerr. 2001. Permits for cash: a fair and equitable resolution to the public land range war. Rangelands 23:22-24.

Smathers, R.L., C.C. Gibson, and N.R. Rimbey. 1998a. Stocker-200 head budget; no wintering; bought in spring; sold in fall. EBBST3-98. Univ. of Ida.. Dept. of Agr. Econ. and Rural Soc. Moscow, Ida.

Smathers, R.L., J.A. Church, C.W. Gray, and N.R. Rimbey. 1998b. Cow-calf budget 250 cow: summer on private range, winter feeding necessary. Univ. of Ida., College of Agr. EBB-CC1-98. Moscow, Ida. Available online at http://www.uidaho.edu/ag/agecon/livestockpub.html.

Smith, A.H. and W.E. Martin. 1972. Socioeconomic behavior of cattle ranchers with implications for rural community development in the West. Amer. J. Agr. Econ. 54:217-225.

Spahr, R. and M.A. Sunderman. 1995. Additional evidence on the homogeneity of the value of government grazing leases and changing attributes for ranch value. J. of Real Estate Res. 10:601-616.

Spahr, R. and M.A. Sunderman. 1998. Property tax inequities on ranch and farm properties. Land Econ. 74:374-389.

Stern, B.S. 1998. Permit value: a hidden key to the public land grazing dispute. M.S. Thesis, Univ. of Mont., Mizzoula, Mont.

Sullivan, R.P. and J.D. Libbin. 1987. Goals of New Mexico farmers. N.M.. State Univ., Agr. Exp. Sta. Rep. 606. Las Cruces, N.M

Sunderman, M.A. and R. Spahr. 1994 Valuation of government grazing leases. J. of Real Estate Res. 9:179-196.

Tanaka, J.A. and B. Gentner. 2001. Response of public land ranchers to policy changes. In: L.A. Torell, E.T. Bartlett, and R. Larranaga (eds.). Current issues in rangeland resource economics: Proc. of a symposium sponsored by Western Coordinating Committee 55 (WCC-55), N.M. State Univ., Res. Rep. 737, Las Cruces, N.M.
Tittman, P.B. and C.E. Brownell. 1984. Appraisal report estimating fair market rental value of public rangelands in the western United States administered by USDA-Forest Serv. and USDI-Bur. of Land Manage. Vols. 1 and 2. PB84-242205. Springfield, Virg.

Torell, L.A. and S.A. Bailey. 2000. Is the profit motive an important determinant of grazing land use and rancher motive? Selected Papers of Western Agr. Econ. Assoc. Annu. Meeting, Vancouver, B.C., June 29-July 1, 2000. Agr. Econ. Res.: Res. in Agr. and Applied Econ.

http://agecon.lib.umn.edu/waea97.html

Torell, L.A. and F.N. Bledsoe. 1990. 1989 New Mexico private grazing lease arrangements and costs. N.M. State Univ. Agr. Exp. Sta. Res. Rep. 651. Las Cruces, N.M

Torell, L.A., and J.P. Doll. 1991. Public land policy and the value of grazing permits. West. J. Agr. Econ. 16:174-184.

Torell, L.A. and J.M. Fowler. 1985. Market values of ranches and grazing permits in New Mexico, 1984. Agr. Exp. Sta. Research Report No. 570. New Mexico State University, Las Cruces, N.M.

Torell, L. A. and J. M. Fowler. 1986. A model for predicting trends of New Mexico grazing land values. N.M. State Univ. Agr. Exp. Sta. Res. Bull. 723. Las Cruces, N.M.

Torell, L.A. and J.M. Fowler. 1992. Grazing fees: how much is fair? N.M. State Univ. Agr. Exp. Sta. Rep. 666. Las Cruces, N.M.

Torell, L.A. and M.E. Kincaid. 1996. Public land policy and the market value of New Mexico ranches, 1979-1994. J. Range Manage. 49:270-276.

Torell, L.A., J.R. Garrett, and C.T.K Ching. 1981. The economic effects of three changes in public lands grazing policies. J. Range Manage. 34:373-376.

Torell, L.A., S. Ghosh, and J.M. Fowler. 1988 Economic considerations for setting grazing fees on New Mexico state trust lands. N.M State Univ., Agr. Exp. Sta., Spec. Rep. No. 81. Las Cruces, N.M.

Torell, L.A., J.M. Hawkes, and S.A. Bailey. 2000. Range livestock cost-and-return estimates for New Mexico, 1997. N.M. State Univ. Agr. Exp. Sta. Rep. 738. Las Cruces, N.M.

Torell, L.A., N.R. Rimbey, J.A. Tanaka, and S.A. Bailey. 2001. The lack of a profit motive for ranching: implications for policy analysis. In: L.A. Torell, E.T. Bartlett, and R. Larranaga (eds.). Current issues in rangeland resource economics: Proc. of a symposium sponsored by Western Coordinating Committee 55 (WCC-55), N.M. State Univ., Res. Rep. 737, Las Cruces, N.M.

Torell, L.A., L.W. Van Tassell, N.R. Rimbey, E.T. Bartlett, T. Bagwell, P. Burgener, and J. Coen. 1993. The value of public land forage and the implications for grazing fee policy. N.M. State Univ., Agr. Exp. Sta. Bull. No. 767. Las Cruces, N.M.

U.S. Department of Agriculture. 1998. A time to act: a report of the USDA National Commission on Small Farms. USDA Commission on Small Farms, Misc. Pub. 1545, Washington, D.C.
U.S. Department of Agriculture/U. S. Department of Interior (USDA/USDI). 1986. Grazing fee review and evaluation, final report 1979-1985: a report from the Secretaries of Agriculture and Interior. Washington, D.C.

U.S. Department of Agriculture/U.S. Department of Interior (USDA/USDI). 1992. Grazing fee review and evaluation update of the 1986 final report: a report from the Secretaries of Agriculture and Interior. Washington, D.C.

U.S. Department of Agriculture National Agricultural Statistical Service (USDANASS). 2001. Agricultural prices monthly. Available online at http://usda.mannlib.cornell.edu/reports/nassr/price/pap-bb/.

U.S. Department of Interior/U.S. Department of Agriculture (USDI/USDA). 1977. Study of fees for grazing livestock on federal lands: a report from the Secretaries of Agriculture and Interior. Washington, D.C.

U. S. Department of Interior/U. S. Department of Agriculture (USDI/USDA). 1993. Incentive-based grazing fee system for public rangeland administered by the Bur. of Land Manage. and U.S. Forest Serv. A report from the Secretaries of Interior and Agriculture, Washington, D.C.

U. S. Department of Interior/U. S. Department of Agriculture (USDI/USDA). 1994. Rangeland reform '94: draft environmental impact statement. Washington, D.C.

Van Kooten, G.C. and E.H. Bulte. 2000. The economics of nature: managing biological assets. Blackwell Publishers. Malden, Mass.

Van Tassell, L.W and S.M. McNeley. 1997. Factors affecting private rangeland lease rates. J. Range Manage. 50:178-184

Van Tassell, L.W., L.A. Torell, N.R. Rimbey, and E.T. Bartlett. 1997. Comparison of forage value on private and public grazing leases. J. Range Manage. 50:300-306

Whittlesey, N.K., R.G. Huffaker, and W.R. Butcher. 1993. Grazing policy on public lands. Choices 3 ${ }^{\text {rd }}$ Quarter:15-19.

Workman, J.P. 1986. Range economics. MacMillan Publishing Co., New York, N.Y.

Workman, J.P. 1988. Federal grazing fees: a controversy that won't go away. Rangelands. 10:128-130.

Workman, J. P. and K. H. King. 1982. Utah Cattle Ranch Prices. Utah Science 43:78-81.

Xu, F., R.C. Mittelhammer, and L.A. Torell. 1994. Modeling nonnegativity via truncated logistic and normal distributions: an application to ranch land price analysis. Western J. Agr. Econ. 19:102-114.

Young, K.D. and C.R. Shumway. 1991. Cowcalf producer's perceived profit-maximization objective: a logit analysis. Southern J. Agr. Econ. 23:129-136. 